\title{
Abomasal secretion and gastrin blood level in sheep fed diets with different fibre content*
}

\author{
W. Korczyński' ${ }^{1}$ Z. Długołęcka, B. Kowalik, J. Rutkowski \\ and T. Żebrowska
}

The Kielanowski Institute of Animal Physiology and Nutrition, Polish Academy of Sciences 05-110 Jabłonna, Poland

\begin{abstract}
The effect of dietary fibre on abomasal secretion and gastrin postprandial level was studied in four sheep. Two isonitrogenous diets differing only in crude fibre content (LFD, 14\% or HFD, 23\%) were used. Volume, hydrogen and chloride ion output, sodium concentration in pure abomasal juice were higher in HFD treatment. Pepsin activity and $\mathrm{pH}$ was lower in that group, while both treatments did not affect protein output and potassium concentration. Postprandial gastrin serum concentration was elevated at 30, 60 and 120 min in HFD as compared to LFD group. Results suggest that fibre stimulates abomasal secretion and elevates gastrin level.
\end{abstract}

KEY WORDS: gastric juice, abomasum, fibre, gastrin, sheep

\section{INTRODUCTION}

Fibre in the GI tract of monogastric animals influence bile and pancreatic secretion and exert trophic action on GI tract tissue, which leads to an enlargement of GI tract mass (Stanogias and Pearce, 1985). In the simple-stomached animals, fibre modifies the gastric emptying rate, pancreatic and bile secretion, and also stimulates gastric secretion (Low, 1985; Tadesse, 1986). In contrast to monogastrics animals, data concerning the influence of dietary fibre on abomasal secretion in ruminants is scarce.

\footnotetext{
${ }^{*}$ Supported by the State Comitteee for Scientific Research, Grant No. 5P06E 03412

${ }^{1}$ Corresponding author: e-mail: w.korczynski@ifzz.pan.pl
} 


\section{MATERIAL AND METHODS}

The study was carried out on four Polish Merino male sheep of $46 \pm 2.4 \mathrm{~kg} \mathrm{BW}$. The animals were fed - in turn - two isonitrogenous diets - 14\% crude protein (CP) in DM, that consisted of meadow hay, rapeseed meal and barley. Crude fibre DM content was adjusted to $14 \%$ in the low fibre diet (LFD) and $24 \%$ in the high fibre diet (HFD). The animals were adapted to the diet 10 days before surgery and between the treatments. The daily allowance was divided into four equal portions given every $6 \mathrm{~h}$. The sheep were prepared with innervated fundic abomasal pouches (Grosskopf, 1954). A round base cannulae made from medical grade silicon was placed in the pouch and kept open. One day before each experiment, animals were equipped with catheters in external jugular vein. Abomasal juice was collected $14 \mathrm{~h}$ per day, during 4 consecutive days for each treatment. The juice was collected every hour and kept in crashed ice. Blood sample for gastrin determination was collected 20 min before feeding $(8.00,14.00,20.00)$ and every $30 \mathrm{~min}$ for $2 \mathrm{~h}$ after. Protein concentration in abomasal juice was measured by the Lowry method, $\mathrm{Cl}$ ions concentration by the method of Vohlard (AOAC, 1990) and $\mathrm{Na}$ and $\mathrm{K}$ concentration by flammable atomic absorption method. Total acidity of abomasal juice was measured by titration $0.1 \mathrm{~N}$ $\mathrm{NaOH}$. Pepsin (EC 3.4.23.1) activity was measured according to Ryle (1970). Blood gastrin level was measured by RIA (Konturek et al., 1982). All values are expressed as means $\pm \mathrm{SD}$. Statistical significance of difference was assessed by Kruskall-Wallis test, Wilcoxon- paired test (gastrin) using STATISTICA 5.1 software (StatSoft, Tulsa, OK, USA). $\mathrm{P}<0.05$ was assumed as the level of the significant statistical difference.

\section{RESULTS}

Most of the parameters of abomasal secretion were significantly higher in animals fed HFD than LFD (Table 1). Only pepsin activity in abomasal juice was significantly lower in the HFD group.

Table 1. Abomasal juice secretion in sheep fed diets with different fibre content (means, $n=96$ )

\begin{tabular}{|c|c|c|c|c|c|}
\hline & \multicolumn{4}{|c|}{ Diet } & \multirow{2}{*}{$\mathrm{P}<$} \\
\hline & LFD & SD & HFD & SD & \\
\hline Volume, $\mathrm{ml} \mathrm{h}^{-1}$ & 11.72 & 5.92 & 13.04 & 3.63 & 0.01 \\
\hline $\mathrm{pH}$ & 1.52 & 0.21 & 1.48 & 0.21 & 0.05 \\
\hline $\mathrm{H}^{+}$output, $\mathrm{mmol} \mathrm{h}^{-1}$ & 0.71 & 0.47 & 0.75 & 0.38 & 0.05 \\
\hline $\mathrm{Cl}^{-}$output, $\mathrm{mmol} \mathrm{h}^{-1}$ & 1.77 & 0.93 & 1.93 & 0.60 & 0.001 \\
\hline $\mathrm{Na}^{+}$concentration, mmol $\mathrm{l}^{-1}$ & 1.98 & 0.41 & 1.67 & 0.31 & 0.05 \\
\hline $\mathrm{K}^{+}$concentration, $\mathrm{mmol}^{-1}$ & 0.11 & 0.03 & 0.11 & 0.03 & NS \\
\hline Pepsin activity, IU ml ${ }^{-1}$ & 0.70 & 0.32 & 0.50 & 0.35 & 0.001 \\
\hline Protein output, $\mathrm{mg} \mathrm{h}^{-1}$ & 35.27 & 20.17 & 30.88 & 9.15 & NS \\
\hline
\end{tabular}

NS - not statistically significant 
Gastrin serum concentrations at $0.5,1$ and $2 \mathrm{~h}$ after feeding were significantly higher in animals, which have received HFD. There was a tendency $(\mathrm{P}=0.504)$ towards higher preprandial (control) gastrin concentration in HFD animals. However, gastrin serum level up to $2 \mathrm{~h}$ after feeding was similar in each treatment (HFD or LFD) (Table 2).

Table 2. Gastrin serum concentration $\left(\mathrm{pmol} \mathrm{1}^{-1}\right)$ in sheep fed diets with different fibre content (means, $\mathrm{n}=24)$

\begin{tabular}{lccllc}
\hline \multirow{2}{*}{$\begin{array}{l}\text { Time after } \\
\text { feeding, } \mathrm{h}\end{array}$} & \multicolumn{3}{c}{ Diet } & \multirow{2}{*}{$\mathrm{P}<$} \\
\cline { 2 - 5 } 0 & LFD & SD & HFD & SD & \\
\hline 0.5 & 51.06 & 20.97 & 68.46 & 42.63 & NS \\
1 & 52.80 & 22.80 & 70.10 & 40.40 & 0.05 \\
1.5 & 49.41 & 25.19 & 67.20 & 44.27 & 0.05 \\
2 & 50.60 & 27.54 & 63.59 & 29.98 & NS \\
\hline
\end{tabular}

NS - not statistically significant

\section{DISCUSSION}

The results are in general agreement with our previous data from pigs with innervated and denervated gastric pouches (Korczyński et al., 1997). Dietary fibre because its water binding properties (distension effect), can activate the vagal and intramural nervous reflexes in the area of the stomach and secretory mechanisms (Low, 1985) may increase GI tract cells proliferation and gastrin release (Johnson, 1988). As a substrate for rumen fermentation fibre is turned into volatile fatty acids (VFA) - potent stimulators of abomasal secretion (Hill, 1960). However, acetic and butyric acid concentration in the rumen $2 \mathrm{~h}$ after feeding was not different between the LFD and HFD diet (Korczyński, 2000). In this study $\mathrm{Cl}^{-}$ion output was higher than measured in preruminat calves (Guilloteau and Toullec, 1983). Moreover, we cannot confirm the findings of mentioned authors who postulated the cyclic variations of the $\mathrm{Cl}^{-}$level in abomasal juice (data not shown). Lower pepsin activity cannot be fully explained as an effect of possible immobilization (diluting) how it was observed in the study on rats (Shah et al., 1986). However, pepsin activity in duodenal digesta was also lower in sheep fed HFD then LFD (Korczyński, 2000). Feeding has no effect on blood gastrin concentration measured every $30 \mathrm{~min}$ up to $2 \mathrm{~h}$. It confirms the results of Carter et al. (1990) who have not found changes in blood gastrin level in sheep fed lucerne hay few times a day. Also, in the study of Thorniley et al. (1996) there were no correlation between gastrin level and feeding in cows and sheep. Higher postprandial gastrin blood concentration at 30,60 and 120 min in HFD fed animals, cannot be related to stimulatory effect of proteins, because the diets were isonitronogenous. 


\section{CONCLUSIONS}

The results presented indicate that dietary fibre can stimulate abomasal secretion in sheep and influence blood level of gastrin.

\section{REFERENCES}

AOAC, 1990. Association of Official Analytical Chemists, Official Methods of Analysis. 15 Edition. Washington, DC

Carter R.R., Grovum W.L., Greenberg G.R., 1990. Parotid secretion patterns during meals and their relationships to the tonicity of body fluids and to gastrin and pancreatic polypeptide in sheep. Brit. J. Nutr. 63, 319-327

Grosskopf J.F.W., 1954. A simplified operation for the preparation of abomasal pouches in calves. J. S.A.V.M.A. 25, 59-62

Guilloteau P., Toullec R., 1983. Circadian changes in the abomasal secretions of the preruminant calf. Reprod. Nutr. Develop. 23, 967-977

Hill K.J., 1960. Abomasal secretion in the sheep. J. Physiol. 154, 115-132

Johnson L.R., 1988. Regulation of gastrointestinal mucosal growth. Physiol. Rev. 2, 456-503

Konturek S.J., Jaworek J., Bielański W., Cieszkowski M., Dobrzańska M., Coy D.H., 1982. Comparison of enkephalin and atropine in the inhibition of vagally stimulated gastric and pancreatic polypeptide release in dogs. Peptides 3, 601-606

Korczyński W., Budzyńska M., Żebrowska T., 1997. The influence of dietary fibre on gastric secretion in pigs. In: P. Laplace, C. Fevier, A. Barbeau (Editors). Proceedings of the VIIth International Symposium on Digestive Physiology in Pigs. Saint-Malo (France), EAAP Publication No. 88, pp. 613-617

Korczyński W., 2000. The influence of dietary fibre and protein on abomasal secretion in sheep. (in Polish). PhD. Thesis. The Kielanowski Institute of Animal Physiology and Nutrition, Jabłonna (Poland)

Low A.G., 1985. The role of dietary fibre in digestion, absorption and metabolism. In: A. Just, H. Jorgensen, J.A. Fernandez (Editors). Digestive Physiology in the Pig. Proceedings of the 3th International Seminar, Copenhagen, pp. 157-180

Ryle A.P., 1970. The porcine pepsins and pepsinogen. In: G.E. Perlman L. Lorand (Editors). Methods in Enzymology. Vol. XIX. Academic Press, pp. 316-337

Shah N., Mahoney R.R., Pellett P.L., 1986. Effect of guar gum, lignin and pectin on proteolytic enzyme levels in the gastrointestinal tract of the rat: a time-based study. J. Nutr. 116, 786-94

Stanogias G., Pearce G.R., 1985. The digestion of fibre by pigs. 3. Effects of the amount and type of fibre on physical characteristics of segments of the gastrointestinal tract. Brit. J. Nutr. 53, 537-548

Tadesse K., 1986. The effect of dietary fibre isolates on gastric secretion, acidity and emptying. Brit. J. Nutr. 55, 507-513

Thorniley G.R., Boyce M.D., Rowe J.B., 1996. Changes in feed intake and Digestability in sheep given virginiamycin. Aust. J. Agr. Res. 47, 539-544 